\title{
PENGARUH PROFITABILITAS, UKURAN PERUSAHAAN, LEVERAGE DAN CASH ON HAND TERHADAP NILAI PERUSAHAAN (STUDI EMPIRIS PADA PERUSAHAAN PERTAMBANGAN BATU BARA YANG GO PUBLIC TAHUN 2017-2018 DI BURSA EFEK INDONESIA)
}

\author{
Dian Widiyati \\ Akuntansi S1, Ekonomi, Universitas Pamulang, Jl. Surya Kencana No. 1, Tangerang Selatan, 15412, Indonesia \\ E-mail: dosen02421@unpam.ac.id
}

\begin{abstract}
This study aims to analyze and obtain empirical evidence about the effect of profitabilitas, company size, leverage and cash on hand for firm value in coal mining companies in Indonesia. Independent variables used in this study is profitabilitas, company size, leverage and cash on hand. Dependent variable used in this study is firm value. The method of analysis of this research used multiple regression analysis. Study's population was coal mining companies listed in Indonesia Stock Exchange (IDX) period among 2017-2018 with amount 22 companies. Data was collected by purposive sampling method so the total sample is 17 companies and 34 data of financial statements companies were taken as study's observation. The result of this research showed that (1) profitabilitas significantly effect firm value, (2) company size significantly effect firm value, (3) leverage significantly effect firm value, (4) cash on hand not significantly effect firm value.
\end{abstract}

Keywords: profitability; company size; leverage; cash on hand; firm value

\section{PENDAHULUAN}

Nilai perusahaan dapat diukur melalui beberapa aspek dimana salah satunya adalah melalui harga pasar saham karena dapat mencerminkan penilaian investor secara keseluruhan atas setiap ekuitas yang dimiliki perusahaan. Semakin tinggi nilai perusahaan, semakin besar kemakmuran yang akan diterima oleh pemilik perusahaan. Pengukuran kinerja keuangan merupakan salah satu indikator yang dipergunakan oleh investor untuk menilai suatu perusahaan dari harga saham di Bursa Efek Indonesia (BEI). Sebelum investor menginvestasikan dananya, investor memerlukan informasi mengenai kondisi perusahaan maupun kondisi di pasar modal dimana informasi yang dimaksud adalah tentang keamanan investasi dan laba yang dicapai dari investasi tersebut.

Nilai perusahaan yang dibentuk melalui indikator harga pasar saham sangat dipengaruhi oleh peluang-peluang investasi. Peluang investasi dapat memberikan sinyal positif tentang pertumbuhan perusahaan dimasa yang akan datang, sehingga akan meningkatkan harga saham. Salah satu return yang diharapkan oleh pemilik perusahaan adalah adanya profit yang dihasilkan oleh suatu perusahaan dalam suatu periode tertentu yang diproksikan melalui rasio keuangan. Profitabilitas merupakan kemampuan perusahaan untuk mendapatkan laba melalui semua kemampuan, dan sumber yang ada seperti kegiatan penjualan, kas, modal, jumlah karyawan, jumlah cabang perusahaan dan lain sebagainya. Suatu perusahaan yang memiliki tingkat profitabilitas yang baik akan lebih memiliki daya tarik bagi investor untuk menanamkan modalnya di perusahaan tersebut. Rasio profitabilitas merupakan skala yang akan digunakan untuk pengukuran profitabilitas perusahaan.

Ukuran perusahaan merupakan faktor yang penting dalam menentukan nilai perusahaan. Ukuran perusahaan menggambarkan besar kecilnya suatu perusahaan yang dapat dilihat dari total aset, jumlah penjualan, rata-rata tingkat penjualan, dan rata-rata total aktiva perusahaan tersebut. Perusahaan dengan ukuran yang lebih besar diperkirakan mempunyai 
kesempatan untuk menarik hutang dalam jumlah yang besar dibandingkan dengan perusahaan yang kecil karena nilai aktiva yang dijadikan jaminan lebih besar dan tingkat kepercayaan bank juga lebih tinggi.

Leverage dapat diartikan sebagai tingkat ketergantungan perusahaan terhadap hutang dalam membiayai kegiatan operasinya. Leverage juga merupakan sarana untuk mendorong peningkatan keuntungan atau pengembalian hasil/nilai tanpa menambah investasi. Teori keagenan memprediksi bahwa perusahaan dengan rasio leverage yang lebih tinggi akan mengungkapkan lebih banyak informasi, karena biaya keagenan perusahaan dengan struktur modal seperti itu lebih tinggi (Jensen dan Meckling, 1976).

Cash on hand adalah kas atau setara kas yang ditahan oleh perusahaan untuk kegiatan operasional perusahaan. Cash on hand merupakan aset yang paling likuid dan rentan untuk disalahgunakan (Christina dan Ekawati, 2014). Menurut Atniati (2013), cash on hand dapat digunakan untuk melakukan beberapa halantara lain adalah untuk pembayaran dividen kepada pemegang saham, melakukan pembelian saham kembali, investasi, maupun disimpan untuk kepentingan masa depan. Pada praktiknya, cash on hand perlu disediakan secara optimal untuk dapat memperlancar kegiatan-kegiatan operasional perusahaan sehingga kegiatan perusahaan untuk mendapatkan laba akan berjalan dengan efektif dan efisien.

\section{TINJAUAN PUSTAKA}

Teori keagenan. Jensen dan Meckling (1976) menjelaskan bahwa "an agency relationship as a contract under which one or more persons (the principal(s)) engage another person (the agent) to perform some service on their behalf which involves delegating some decision making authority to the agent". Terdapat tiga macam biaya keagenan yaitu:

1. Biaya pemantauan (monitoring cost), yaitu biaya yang dikeluarkan dengan tujuan untuk membatasi penyimpangan yang dilakukan oleh pihak manajer dengan mengawasi aktivitas yang dilakukan oleh manajer.

2. Biaya kompensasi insentif (bonding cost), yaitu biaya yang dikeluarkan agar kesempatan yang diberikan kepada manajemen untuk membelanjakan sumber daya tidak akan merugikan pemilik.

3. Biaya kerugian residual(residual cost), yaitu nilai uang yang ekuivalen dengan kesejahteraan yang dialami oleh pemilik. Biaya ini dianggap sebagai biaya yang timbul dari hubungan keagenan dan dinamakan biaya kerugian residual.

Teori agensi menggunakan tiga asumsi sifat manusia yang dikemukakan oleh Eisenhardt (1989:58), yaitu manusia pada umumnya mementingkan diri sendiri (self interest), manusia memiliki daya pikir terbatas mengenai persepsi masa yang akan datang(bounded rationality), dan manusia selalu menghindari risiko (risk adverse).

Nilai perusahaan. Memaksimumkan nilai perusahaan tidak hanya dengan meningkatkan keuntungan perusahaan. Nilai perusahaan dikatakan penting karena dengan tingginya nilai perusahaan maka kemakmuran pemegang saham juga cenderung tinggi. Semakin tinggi harga saham maka nilai perusahaan akan semakin tinggi juga. Dalam penelitian ini nilai perusahaan diproksikan dengan menggunakan Price Book Value (PBV) sesuai pengukuran yang digunakan oleh Budiarso (2019). PBV merupakan nilai yang ditentukan pasar keuangan pada organisasi perusahaan dan manajemen sebagai sebuah perusahaan yang terus tumbuh (Rachmawati dan Triatmoko, 2007). PBV mempunyai beberapa keunggulan sebagai berikut:

1. Nilai buku mempunyai ukuran intutif yang relatif stabil yang dapat diperbandingkan dengan harga pasar. Investor yang kurang percaya dengan metode discounted cash flow dapat menggunakan price book value sebagai perbandingan. 
2. Nilai buku memberikan standar akuntansi yang konsisten untuk semua perusahaan. PBV dapat diperbandingkan antara perusahaan-perusahaan yang sama sebagai petunjuk adanya under atau over valuation.

3. Perusahaan-perusahaan dengan earning negatif, yang tidak bisa dinilai dengan menggunakan price earning ratio (PER) dapat dievaluasi menggunakan price book value ratio $(\mathrm{PBV})$.

Profitabilitas. Tujuan akhir yang ingin dicapai suatu perusahaan adalah memperoleh laba atau keuntungan yang maksimal, di samping hal-hal lainnya. Dengan memperoleh laba yang maksimal seperti yang telah ditargetkan, perusahaan dapat berbuat banyak bagi kesejahteraan pemilik, karyawan serta meningkatkan mutu produk dan melakukan investasi baru. Rasio profitabilitas merupakan rasio untuk menilai kemampuan perusahaan dalam mencari keutungan (Kasmir, 2014:196). Rasio ini juga memberikan ukuran tingkat efektivitas manajemen suatu perusahaan. Pada penelitian ini profitabilitas diproksikan dengan Return on Aset (ROA) sesuai hasil penelitian Akandji et al. (2020). Terjadinya peningkatan laba mampu memberikan sinyal positif kepada para investor bahwa perusahaan tersebut profitabel dan diharapkan dapat memberikan kesejahteraan kepada para pemegang saham melalui pengembalian saham yang tinggi (Pramana dan Mustanda, 2016).

Ukuran perusahaan. Ukuran perusahaan adalah suatu skala dimana dapat diklasifikasikan sebagai besar kecilnya perusahaan dengan berbagai cara antara lain dengan total aset perusahaan, log size perusahaan, nilai pasar saham, dan lain-lain. Selain itu, ukuran perusahaan juga dapat digambarkan melalui total aktiva, jumlah penjualan, rata-rata penjualan aset dan rata-rata total aktiva perusahaan. Total aset dipilih sebagai proksi dari variabel ukuran perusahaan dikarenakan total aset lebih stabil dan representatif dalam menunjukkan ukuran perusahaan dibanding kapitaliasi pasar dan penjualan yang sangat dipengaruhi oleh demand and supply. Variabel ukuran perusahaan dapat diukur dengan menggunakan logaritma natural dari total aset perusahaan Novari dan Lestari (2016). Hal ini karena total aktiva masing-masing perusahaan berbeda bahkan mempunyai selisih yang besar, sehingga dapat menyebabkan nilai yang ekstrim. Untuk menghindari adanya data yang tidak normal tersebut maka dari total aset perlu dikonversi ke dalam bentuk logaritma natural.

Leverage. Perusahaan dengan rasio leverage yang lebih tinggi berusaha menyampaikan lebih banyak informasi sebagai instrumen untuk mengurangi monitoring cost bagi investor. Perusahaan dengan rasio leverage yang lebih tinggi memberikan informasi yang lebih detail dalam laporan tahunan untuk memenuhi kebutuhan informasi bagi investor dibandingkan dengan perusahaan yang memiliki leverage lebih rendah. Leverage juga merupakan sarana untuk mendorong peningkatan keuntungan atau pengembalian hasil/nilai tanpa menambah investasi. Teori keagenan memprediksi bahwa perusahaan dengan rasio leverage yang lebih tinggi akan mengungkapkan lebih banyak informasi. Menurut Wulandari dan Wiksuana (2017), peningkatan leverage bisa memberikan dua macam signal, yaitu berita baik sekaligus berita buruk. Peningkatan leverage menunjukkan berita baik jika peningkatan tersebut merefleksikan kemampuan manajemen untuk meningkatkan nilai. Sebaliknya, hal tersebut menunjukkan berita buruk jika manajer melakukan peningkatan leverage karena terpaksa dan bukan karena alasan efisiensi.

Cash on hand. Kas merupakan salah satu faktor krusial yang dibutuhkan oleh perusahaan untuk membiayai aktivitas operasional perusahaan. Salah satu faktor krusial di posisi arus kas perusahaan adalah arus kas bebas (free cash flow) perusahaan. Arus kas bebas adalah kas yang tersedia di perusahaan yang dapat digunakan untuk berbagai aktivitas (Murhadi, 2013:48). Menurut Brigham dan Houston (2010:109), arus kas bebas adalah arus kas yang tersedia untuk dibayar kepada investor setelah melakukan investasi dalam aset tetap, produk baru, dan modal kerja yang dibutuhkan untuk mempertahankan operasional yang sedang berjalan. Kas atau setara kas yang tersedia setelah pengeluaran perusahaan dalam 
melakukan kegiatan bisnis tersebut disebut free cash flow, yang dapat memberikan penghasilan tambahan melalui investasi tambahan. Menurut Dittmar et.al., 2003 dalam penelitian Toly, et. al (2019), manajer dapat melakukan investasi dengan menggunakan uang perusahaan dan tidak mengungkapkan kepada investor atau pasar modal. Manajer juga dapat mengeluarkan uang pada beban yang tidak diperlukan untuk operasional perusahaan. Selain itu, para manajer yang memiliki kontrol terhadap perusahaan dapat menggunakan uang perusahaan dengan cara menginvestasikan uang tersebut ke suatu investasi yang tidak meningkatkan nilai perusahaan.

\section{METODE PENELITIAN}

Jenis dan sumber data. Penelitian ini merupakan penelitian asosiatif (hubungan), yaitu penelitian yang bertujuan untuk mengetahui hubungan dua variabel atau lebih. Berdasarkan tingkat penjelasan dari kedudukan variabelnya maka penelitian ini bersifat kausal, yaitu the study in which the researcher wants to delineate the cause of one or more problems is called a causal study (Sekaran, 2003:126). Berdasarkan jenis data dan analisis yang digunakan, penelitian ini termasuk penelitian kuantitatif karena mengacu pada perhitungan data yang berupa angka.

Sampel dan teknik pengambilan sampel. Populasi dalam penelitian ini adalah perusahaan pertambangan batu bara yang terdaftar di Bursa Efek Indonesia untuk periode 2017-2018 dengan jumlah perusahaan sebanyak 22 perusahaan. Pengambilan sampel dilakukan menggunakan teknik non-probability sampling dengan metode purposive sampling yaitu pengambilan sampel dengan kriteria-kriteria tertentu. Kriteria sampel dalam penelitian ini adalah sebagai berikut.

a. Perusahaan tergolong dalam industri pertambangan batu bara yang aktif dan terdaftar di Bursa Efek Indonesia periode 2017-2018 secara berturut-turut.

b. Perusahaan menerbitkan laporan keuangan yang diaudit untuk periode yang berakhir pada 31 Desember 2017 sampai dengan 31 Desember 2018.

c. Perusahaan mengungkapkan data yang diperlukan dalam penelitian secara lengkap selama periode 2017-2018.

Berdasarkan kriteria yang telah ditetapkan dengan menggunakan metode purposive sampling, maka sampel dalam penelitian ini sebanyak 17 perusahaan dengan total observasi 34 laporan keuangan perusahaan. Tabel 1 menyajikan operasionalisasi variabel yang digunakan dalam penelitian ini.

Tabel 1. Definisi operasional variabel

\begin{tabular}{ll}
\hline \multicolumn{1}{c}{ Variabel } & \multicolumn{1}{c}{ Rumus } \\
\hline Nilai Perusahaan (NP) & Jumlah ekuitas : Jumlah saham yang beredar \\
Profitabilitas (PRF) & (Laba bersih : Total aktiva) x 100\% \\
Ukuran Perusahaan (UP) & Logaritma natural dari total aset \\
Leverage (LVRG) & (Jumlah hutang : Jumlah ekuitas) x 100\% \\
Cash on Hand (COH) & Logaritma natural dari total cash on hand \\
\hline
\end{tabular}

Metode analisis. Analisis untuk mengetahui seberapa besar suatu variabel independen mempengaruhi variabel dependen dilakukan dengan analisis regresi berganda pada tingkat signifikansi $5 \%$.

1. Analisis deskripsi statistik. Pengukuran yang digunakan adalah nilai minimum, nilai maksimum, nilai rata-rata, standar deviasi dan range. 
2. Pengujian hipotesis

\section{a. Uji asumsi klasik}

Uji normalitas. Uji normalitas bertujuan untuk menguji apakah dalam model regresi variabel independen, variabel dependen atau keduanya mempunyai distribusi normal atau tidak. Pada program E-Views, pengujian normalitas dilakukan dengan JarqueBera test. Uji Jarque-Bera mempunyai nilai Chi-Square dengan derajat bebas dua. Jika hasil uji Jarque-Bera lebih besar dari nilai Chi-Square pada $\alpha=5 \%$, maka hipotesis nol diterima yang berarti data berdistribusi normal. Jika hasil uji Jarque-Bera lebih kecil dari nilai Chi-Square pada $\alpha=5 \%$, maka hipotesis nol ditolak yang artinya tidak berdistribusi normal.

Uji multikolinearitas. Pengujian multikolinearitas bertujuan untuk menguji apakah pada model regresi ditemukan adanya korelasi antar variabel independen. Untuk mendeteksi multikolinearitas, maka dapat dilakukan dengan melihat nilai Tolerance dan Variance Inflation Factor (VIF) serta besaran korelasi antar variabel independen. Uji heteroskedastisitas. Heteroskedastisitas merupakan suatu pelanggaran asumsi dalam persamaan regresi berganda dimana varians dari setiap error dari variabel bebas tidak konstan dari waktu ke waktu. Heteroskedastisitas menyebabkan hasil estimasi dengan OLS akan menghasilkan parameter yang bias, tidak efisien maupun konsisten, artinya koefisien yang dihasilkan bukan dari varian error terkecil. Dalam program E-Views, tes untuk melihat apakah terdapat heterokedastisitas dalam suatu persamaan adalah dengan menggunakan White-test.

b. Analisis korelasi. Korelasi merupakan teknik analisis yang termasuk dalam salah satu teknik pengukuran asosiasi/ hubungan. Pengukuran asosiasi merupakan istilah umum yang mengacu pada sekelompok teknik dalam statistik bivariate yang digunakan pada sekelompok teknik dalam statistik bivariate yang digunakan untuk mengukur kekuatan hubungan antara dua variabel.

c. Analisis regresi berganda. Estimasi parameter model dengan data panel, mengunakan beberapa teknik yaitu:

Model Common Effect (Ordinary Least Square). Model ini merupakan model yang paling sederhana. Dalam estimasinya diasumsikan bahwa setiap untit individu memiliki intersep dan slope yang sama (tidak ada perbedaan pada dimensi ketat waktu). Dengan kata lain, regresi data panel data yang dihasilkan akan berlaku untuk setiap individu.

Model Efek Tetap (The Fixed Effect Model). Model efek tetap adalah model regresi data panel yang didapatkan dengan asumsi bahwa unit cross section dan time series yang digunakan dalam model sudah diketahui terlebih dahulu, MET dalam penelitian ini memiliki konstanta yang bervariasi pada unit cross section dan koefisien konstanta yang mengasumsikan bahwa perbedaan pengaruh dari unit cross section dan time series tercermin dari konstanta yang berbeda-beda.

Model Efek Random (The Random Effect Model). Model ini disebut juga model komponen error. Sama seperti model efek tetap, model ini juga memungkinkan terjadi perbedaan nilai parameter intersep dan koefisien berbeda antar daerah dan antar waktu, yang diekspresikan dalam error. Pada model ini gangguan diasumsikan bersifat acak untuk seluruh populasi. Model ini mengasumsikan bahwa error secara individu tidak saling berkorelasi, begitu juga dengan error kombinasinya. Dengan menggunakan model ini maka kita dapat menghemat pemakaian derajat kebebasan dan tidak mengurangi jumlah seperti pada fixed effect model. Hal ini berimplikasi pada parameter hasil estimasi akan menjadi efisien.

d. Koefisien determinasi. Pengujian ini menguji sejauh mana variasi dari variabel terikat mampu dijelaskan oleh variabel bebasnya. Nilai $\mathrm{R}^{2}$ merupakan fraksi dari 
variasi yang mampu dijelaskan oleh variabel bebas terhadap variabel terikat. Nilai $\mathrm{R}^{2}$ berkisar antara 0-1 persen dan jika nilai mendekati 1 maka semakin baik.

\section{HASIL PENELITIAN DAN PEMBAHASAN}

\subsection{Hasil penelitian}

Variabel penelitian yang digunakan dalam penelitian ini meliputi profitabilitas, ukuran perusahaan, leverage dan cash on hand sebagai variabel independen, nilai perusahaan sebagai variabel dependen. Tabel 2 menunjukkan bahwa variabel UP, LVRG, COH dan NP memiliki nilai rata-rata lebih besar dari nilai standard deviasi. Hal ini menunjukkan bahwa kualitas data dari variabel tersebut baik karena nilai rata-rata yang lebih besar dari nilai standar deviasinya, mengidentifikasikan bahwa standar eror dari variabel tersebut kecil. Sedangkan variabel PRF memiliki nilai rata-rata yang lebih kecil dari nilai standar deviasi sehingga dapat diidentifikasi bahwa standar eror dari variabel tersebut besar.

Tabel 2. Statistik deskriptif

\begin{tabular}{lrrrrr}
\hline & PRF & UP & LVRG & COH & NP \\
\hline Mean & 13.28390 & 28.93598 & 261.9431 & 13.23263 & 226.6613 \\
Median & 9.605551 & 29.33117 & 72.71183 & 13.31419 & 180.8792 \\
Maximum & 54.24701 & 32.22463 & 3405.558 & 20.18026 & 619.1077 \\
Minimum & -8.072215 & 23.66882 & 16.06180 & 6.196444 & 3.247988 \\
Std. Dev. & 14.32070 & 2.092425 & 607.6597 & 3.431649 & 190.0918 \\
Skewness & 0.873761 & -0.843245 & 4.364186 & 0.263956 & 0.490684 \\
Kurtosis & 3.540050 & 3.522901 & 22.56038 & 2.964680 & 1.892745 \\
Jarque-Bera & 4.739436 & 4.416706 & 649.9569 & 0.396581 & 3.101221 \\
Probability & 0.093507 & 0.109881 & 0.000000 & 0.820132 & 0.212118 \\
Sum & 451.6526 & 983.8234 & 8906.066 & 449.9095 & 7706.485 \\
Sum Sq. Dev. & 6767.722 & 144.4820 & 12185262 & 388.6150 & 1192452. \\
Observations & 34 & 34 & 34 & 34 & 34 \\
\hline
\end{tabular}

Sumber: Data olah, 2020

\section{Uji asumsi klasik}

Gambar 1 menunjukkan bahwa nilai Jarque-Bera sebesar 0,451184 dengan nilai probabilitas sebesar 0,798044 dimana nilai probabilitas lebih besar dari 0,05 yang berarti bahwa nilai residual berdistribusi normal.

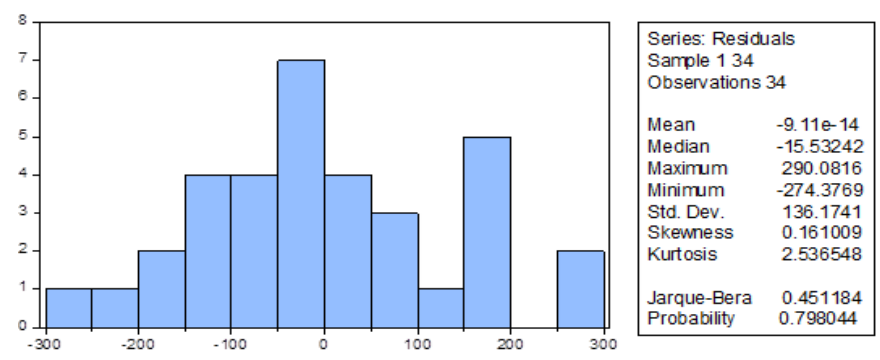

Gambar 1. Uji normalitas

Tabel 3 menunjukkan bahwa hasil perhitungan nilai centered VIF untuk variabel PRF, UP, LVRG dan $\mathrm{COH}$ memiliki nilai kurang dari 10. Jadi dapat disimpulkan bahwa tidak terjadi multikolinearitas antar variabel independen dalam model penelitian ini. 
Tabel 3. Uji multikolinearitas

\begin{tabular}{lc}
\hline \multicolumn{1}{c}{ Variabel } & Variance Inflation Factor (VIF) \\
\hline PRF & 1.294196 \\
UP & 1.213506 \\
LVRG & 1.243109 \\
COH & 1.179510 \\
\hline PRF adalah Profitabilitas, UP adalah Ukuran Perusahaan, LVRG adalah Leverage, dan COH adalah Cash on \\
Hand
\end{tabular}

Tabel 4 menunjukkan bahwa nilai Obs*R-Squared mempunyai nilai prob. Chi-Square sebesar 0,0741, sehingga hal ini berarti bahwa tidak ada gejala heterokedastisitas yang terjadi.

Tabel 4. Uji heterokedastisitas

\begin{tabular}{cc}
\hline Obs*R-Squared & Prob. Chi-Square \\
\hline 22.22751 & 0,0741 \\
\hline
\end{tabular}

Sumber: Data olah, 2020

Tabel 5 menunjukkan bahwa semua variabel independen berkorelasi dengan variabel dependen. Hal ini berarti bahwa antara variabel independen memiliki hubungan dengan variabel dependen.

Tabel 5. Analisis korelasi

\begin{tabular}{lrrrrr}
\hline & \multicolumn{1}{c}{ PRF } & \multicolumn{1}{c}{ UP } & \multicolumn{1}{c}{ LVRG } & \multicolumn{1}{c}{ COH } & \multicolumn{1}{c}{ NP } \\
\hline PRF & 1 & 0.116 & -0.377 & -0.176 & 0.433 \\
UP & 0.116 & 1 & 0.155 & 0.305 & 0.515 \\
LVRG & -0.377 & 0.155 & 1 & 0.029 & -0.324 \\
COH & -0.176 & 0.305 & 0.029 & 1 & 0.089 \\
NP & 0.433 & 0.515 & -0.324 & 0.089 & 1 \\
\hline
\end{tabular}

PRF adalah Profitabilitas, UP adalah Ukuran Perusahaan, LVRG adalah Leverage, dan COH adalah Cash on Hand

Sumber: Data olah, 2020

Pengujian hipotesis

Pengujian hipotesis dilakukan dengan melakukan analisis regresi berganda melalui beberapa model pengujian yaitu common effect model, fixed effect model dan random effect model. Tahap pertama yang akan dilakukan yaitu uji Chow. Tabel 6 menunjukkan bahwa nilai probabilitas pada F-test sebesar 0,0000 dan nilai Chi-Square sebesar 0,0000, kedua nilai tersebut lebih kecil dari 0,05 sehingga dapat disimpulkan bahwa model mengikuti Fixed Effect Model (FEM).

Tabel 6. Uji Chow

\begin{tabular}{cc}
\hline Prob. F-test & Chi-Square \\
\hline 0,0000 & 0,0000 \\
\hline Sumber: Data olah, 2020 &
\end{tabular}

Tahap kedua yang akan dilakukan yaitu uji Hausman. Tabel 7 menunjukkan bahwa nilai probabilitas pada nilai Chi-Square sebesar 0,0074, nilai tersebut lebih kecil dari 0,05 sehingga dapat disimpulkan bahwa menurut uji Hausman, model mengikuti Fixed Effect Model (FEM). 
Tabel 7. Uji Chow

\begin{tabular}{cc}
\hline Prob. F-test & Chi-Square \\
\hline 0,0000 & 0,0000 \\
\hline Sumber: Data olah, 2020 &
\end{tabular}

Berdasarkan Tabel 8, hasil analisis regresi berganda menunjukkan bahwa nilai probabilitas profitabilitas (PRF) terhadap nilai perusahaan (NP) adalah sebesar 0,0043 $(<0,05)$, hal ini berarti bahwa profitabilitas berpengaruh terhadap nilai perusahaan. Nilai probabilitas ukuran perusahaan (UP) terhadap nilai perusahaan (NP) adalah sebesar 0,0002 $(<0,05)$, hal ini berarti bahwa ukuran perusahaan berpengaruh terhadap nilai perusahaan. Nilai probabilitas leverage (LVRG) terhadap nilai perusahaan (NP) adalah sebesar 0,0229 $(<0,05)$, hal ini berarti bahwa leverage berpengaruh terhadap nilai perusahaan. Nilai probabilitas cash on hand $(\mathrm{COH})$ terhadap nilai perusahaan (NP) adalah sebesar 0,9503 $(>0,05)$, hal ini berarti bahwa cash on hand tidak berpengaruh terhadap nilai perusahaan. Tabel 8 juga menunjukkan bahwa nilai R-Squared sebesar 0,997173 sehingga besarnya nilai koefisien determinasi adalah sebesar $99,72 \%$. Hal ini menunjukkan bahwa variasi dari variabel terikat yang mampu dijelaskan oleh variabel bebas adalah sebesar $99,72 \%$. Persamaan regresi yang dihasilkan adalah sebagai berikut.

$$
\mathrm{Y}=3,066262 \mathrm{PRF}+176,3637 \mathrm{UP}-0,022140 \mathrm{LVRG}-0,626989 \mathrm{COH}-4.903,231
$$

Tabel 8. Analisis Regresi Berganda Model Fixed Effect Model

\begin{tabular}{lcc}
\hline \multicolumn{1}{c}{ Variabel } & Koefisien & Probabilitas \\
\hline Konstanta & $-4903,231$ & 0.0002 \\
PRF & 3.066262 & 0.0043 \\
UP & 176.3637 & 0.0002 \\
LVRG & -0.022140 & 0.0229 \\
COH & -0.626989 & 0.9503 \\
$\mathrm{R}^{2}$ & 0.997173 & \\
\hline
\end{tabular}

PRF adalah profitabilitas, UP adalah ukuran perusahaan, LVRG adalah leverage, dan COH adalah cash on hand

Sumber: Data olah, 2020

\subsection{Pembahasan}

Berdasarkan pengujian regresi berganda sebagaimana telah dijelaskan pada bagian sebelumnya, interpretasi hasil disajikan dalam 4 bagian. Penjelasan keempat bagian tersebut adalah sebagai berikut.

Pengaruh profitabilitas (PRF) terhadap nilai perusahaan (NP). Berdasarkan Tabel 8, variabel PRF menunjukkan koefisien regresi positif sebesar 3,066262. Probabilitas menunjukkan nilai yang lebih kecil dari 0,05 yaitu 0,0043 . Hal ini berarti bahwa tingkat signifikansinya lebih kecil dari $\alpha=5 \%$, sehingga hipotesis ke-1 berhasil didukung atau $\mathrm{H}_{0}$ ditolak. Penelitian ini berhasil membuktikan bahwa profitabilitas berpengaruh terhadap nilai perusahaan. Hasil ini mendukung penelitian yang dilakukan oleh Widyanti (2016) yang menunjukkan bahwa profitabilitas berpengaruh signifikan terhadap nilai perusahaan. Hasil penelitian ini tidak konsisten dengan penelitian yang dilakukan oleh Chetty et al., (2015) yang menunjukkan bahwa profitabilitas secara signifikan tidak berpengaruh terhadap nilai perusahaan. Sehingga dapat disimpulkan bahwa semakin tinggi nilai profit suatu perusahaan dapat meningkatkan nilai perusahaan dan sebaliknya.

Pengaruh ukuran perusahaan (UP) terhadap nilai perusahaan (NP). Berdasarkan Tabel 8, variabel UP menunjukkan koefisien regresi positif sebesar 176,3637. Probabilitas menunjukkan nilai yang lebih kecil dari 0,05 yaitu 0,0002 . Hal ini berarti bahwa tingkat signifikansinya lebih kecil dari $\alpha=5 \%$, sehingga hipotesis ke-2 berhasil didukung atau $\mathrm{H}_{0}$ 
ditolak. Penelitian ini berhasil membuktikan bahwa ukuran perusahaan berpengaruh terhadap nilai perusahaan. Hasil ini mendukung penelitian yang dilakukan oleh Pramana dan Mustanda (2016) yang menunjukkan bahwa ukuran perusahaan berpengaruh signifikan terhadap nilai perusahaan. Hasil penelitian ini tidak konsisten dengan penelitian yang dilakukan oleh Meidiawati dan Mildawati (2016) yang menunjukkan bahwa ukuran perusahaan tidak berpengaruh terhadap nilai perusahaan. Sehingga dapat disimpulkan bahwa semakin tinggi ukuran perusahaan maka semakin tinggi nilai suatu perusahaan dan sebaliknya.

Pengaruh leverage (LVRG) terhadap nilai perusahaan (NP). Berdasarkan Tabel 8, variabel LVRG menunjukkan koefisien regresi negatif sebesar -0,022140. Probabilitas menunjukkan nilai yang lebih kecil dari 0,05 yaitu 0,0229. Hal ini berarti bahwa tingkat signifikansinya lebih kecil dari $\alpha=5 \%$, sehingga hipotesis ke-3 berhasil didukung atau $\mathrm{H}_{0}$ ditolak. Hasil penelitian ini mendukung penelitian dari Wulandari dan Wiksuana (2017) yang menunjukkan bahwa leverage berpengaruh signifikan terhadap nilai perusahaan. Hasil ini tidak konsisten dengan penelitian yang dilakukan oleh Maspupah (2014) yang menunjukkan bahwa leverage tidak berpengaruh terhadap nilai perusahaan. Sehingga dapat disimpulkan bahwa semakin tinggi leverage maka semakin rendah nilai perusahaan dan sebaliknya. Hal ini menunjukkan bahwa perusahaan yang memiliki hutang tinggi cenderung tidak menggunakan dana yang didapatkan dari hutang untuk kegiatan yang produktif.

Pengaruh cash on hand (COH) terhadap nilai perusahaan (NP). Berdasarkan Tabel 8, variabel $\mathrm{COH}$ menunjukkan koefisien regresi negatif sebesar -0,626989. Probabilitas menunjukkan nilai yang lebih besar dari 0,05 yaitu 0,9503 . Hal ini berarti bahwa tingkat signifikansinya lebih besar dari $\alpha=5 \%$, sehingga hipotesis ke-4 tidak berhasil didukung atau $\mathrm{H}_{0}$ ditolak. Hasil penelitian ini tidak konsisten dengan penelitian yang dilakukan oleh Arianto, et. al (2019) yang menunjukkan bahwa cash on hand berpengaruh terhadap nilai perusahaan.

\section{KESIMPULAN DAN SARAN}

\subsection{Kesimpulan}

Berdasarkan hasil analisis dan pembahasan yang telah dilakukan terhadap permasalahan dengan menggunakan analisis regresi berganda, diperoleh kesimpulan sebagai berikut:

1. Profitabilitas berpengaruh signifikan terhadap nilai perusahaan pada perusahaan pertambangan batu bara yang terdaftar di BEI pada periode 2017-2018.

2. Ukuran perusahaan berpengaruh signifikan terhadap nilai perusahaan pada perusahaan pertambangan batu bara yang terdaftar di BEI pada periode 2017-2018.

3. Leverage berpengaruh signifikan terhadap nilai perusahaan pada perusahaan pertambangan batu bara yang terdaftar di BEI pada periode 2017-2018.

4. Cash on Hand tidak berpengaruh signifikan terhadap nilai perusahaan pada perusahaan pertambangan batu bara yang terdaftar di BEI pada periode 2017-2018.

\subsection{Saran}

Saran yang dapat diberikan untuk penelitian selanjutnya adalah sebagai berikut:

1. Penelitian selanjutnya diharapkan dapat menggunakan sampel penelitian yang tidak hanya dari industri pertambangan batu bara tetapi juga mencakup industri lainnya yang terdaftar di Bursa Efek Indonesia (BEI).

2. Pengukuran terhadap variabel leverage pada penelitian selanjutnya dapat menggunakan proksi lain.

3. Penelitian selanjutnya diharapkan dapat menambah variabel-variabel lain yang diduga mempengaruhi nilai perusahaan. 


\section{DAFTAR PUSTAKA}

Akandji, V., Tinangon, J., \& Pontoh, W. (2020). Analisis rentabilitas pada industri perhotelan yang terdaftar di Bursa Efek Indonesia. Going Concern : Jurnal Riset Akuntansi, 15(2), 62-68. https://doi.org/10.32400/gc.15.2.27853.2020

Atniati, D. (2013). Analisis motif perusahaan dalam menentukan besarnya cash holding. Thesis. http://sinta.ukdw.ac.id

Brigham, E. F., \& Houston, J. F. (2010). Dasar-dasar manajemen keuangan, Edisi 10. Jakarta: Salemba Empat.

Budiarso, N. S. (2019). Dividend policy on controlling and non-controlling shareholders: Ccase in Indonesia. Investment Management and Financial Innovations, 16(2), 336347.https://doi.org/10.21511/imfi.16(2).2019.28

Chetty, S., Naidoo, R.,\&Seetharam, Y. (2015). The impact of corporate social responsibility on firms' financial performance in South Africa.Contemporary Economics, 9(2), 193214. http://10.5709/ce.1897-9254.167

Christina, Y., \& Ekawati, E. (2014). Excess cash holdings dan kepemilikan institusional pada perusahaan manufaktur yang terdaftar di BEI.Matrik : Jurnal Manajemen, Strategi Bisnis dan Kewirausahaan, $\quad 8(1), \quad$ 1-10. https://ojs.unud.ac.id/index.php/jmbk/article/view/8051

Eisenhardt, K. (1989). Agency Theory: An assessment and review. The Academy of Management Review, 14(1), 57-74. www.jstor.org/stable/258191

Jensen, M. C., \& Meckling,W. H. (1976). Theory of the firm: Managerial behavior, agency costs, and ownership structure.Jurnal of Financial Economics,3(4), 305-360. https://doi.org/10.1016/0304-405X(76)90026-X

Kasmir. (2014). Analisis laporan keuangan. Jakarta: Rajawali Pers.

Maspupah, I. (2014). Pengaruh ukuran perusahaan, profitabilitas, tanggung jawab sosial perusahaan, kepemilikan institutional, pertumbuhan perusahaan dan struktur modal terhadap nilai perusahaan (Studi empiris pada perusahaan properti yang masuk kedalam kelompok daftar efek syariah periode 2009-2012). Skripsi. http://digilib.uinsuka.ac.id/id/eprint/13434.

Meidiawati, K., \& Mildawati, T. (2016). Pengaruh size, growth, profitabilitas, struktur modal, kebijakan dividen terhadap nilai perusahaan. Jurnal Ilmu dan Riset Akuntansi, 5(2). http://garuda.ristekbrin.go.id/documents/detail/672120

Murhadi, W. R. (2013). Analisis laporan keuangan: proyeksi dan valuasi saham. Jakarta: Salemba Empat.

Novari, P. M., \& Lestari, P. V. (2016). Pengaruh ukuran perusahaan, leverage, dan profitabilitas terhadap nilai perusahaan pada sektor properti dan real estate. E-Jurnal Manajemen, $\quad$ 5(9). 5671-5694. https://ojs.unud.ac.id/index.php/Manajemen/article/view/22690

Pramana, I. G. N. G. D., \& Mustanda, I. K. (2016). Pengaruh profitabilitas dan size terhadap nilai perusahaan dengan CSR sebagai variabel pemoderasi. E-Jurnal Manajemen, 5(1), 561 -594. https://ojs.unud.ac.id/index.php/Manajemen/article/view/17586

Rachmawati, A., \& Triatmoko, H.(2007).Analisis faktor-faktor yang mempengaruhi kualitaslaba dan nilai perusahaan. Simposium Nasional Akuntansi 10, Makasar. http://pdeb.fe.ui.ac.id/?p=7157

Sekaran, U. (2003). Research methods for business: A skill-building approach, 14th Edition.New York: John Wiley and Sons Inc.

Toly, A. A., Claudya, C., Santoso, R., \& Grace, F. (2019).Analisa pengaruh corporate governance, ownership structure dan cash on hand terhadap nilai perusahaan. Jurnal Riset Keuangan dan Akuntansi, 5(2), 31-51. https://journal.uniku.ac.id/index.php/jrka 
Widyanti, C. F. (2016). Pengaruh profitabilitas terhadap nilai perusahaan dengan Corporate Social Responsibility (CSR) sebagai variabel pemoderasi pada perusahaan sektor agrikultur yang terdaftar di BEI tahun 2012-2014. Skripsi. http://eprints.perbanas.ac.id/1716/

Wulandari, N. M. I., \& Wiksuana, I. G. B. (2017). Peranan Corporate Social Responsibility dalam memoderasi pengaruh profitabilitas, leverage dan ukuran perusahaan terhadap nilai perusahaan. E-JurnalManajemen,6(3),1278-1311. https://ojs.unud.ac.id/index.php/Manajemen/article/view/27466 